\title{
CDKN1C wt Allele
}

National Cancer Institute

\section{Source}

National Cancer Institute. CDKN1C wt Allele. NCI Thesaurus. Code C49510.

Human CDKN1C wild-type allele located in the vicinity of 11 p15.5 and is approximately 2 $\mathrm{kb}$ in length. This allele, which encodes cyclin-dependent kinase inhibitor $1 \mathrm{C}$ protein, plays a negative role in the regulation of cellular proliferation by inhibiting several G1 cyclin/Cdk complexes. Mutations of the gene, which generates variant alleles have been implicated in both sporadic cancers and Beckwith-Wiedemann syndrome, suggesting that it is a tumor suppressor candidate. 